\title{
Partition, independence, and maritime networks in South Asia
}

\author{
Kenmei TSUBOTA, Atiya Habeeb KIDWAI, César DUCRUET
}

Pre-final version of the chapter published in Ducruet C. (Ed.) (2017) Advances in Shipping Data

Analysis and Modeling. Tracking and Mapping Maritime Flows in the Age of Big Data, Routledge

Studies in Transport Analysis, pp. 415-431.

The British rule had been fully entrenched in most parts of South and Southeast Asia by the late Nineteenth Century. The countries in these regions had been converted into colonies and along with other British colonies elsewhere in the world; they were well connected to the United Kingdom, as stated as early as 1776 by Adam Smith: "What goods could bear the expense of land-carriage between London and Calcutta? ... Those two cities, however, at present carry on a very considerable commerce with each other, and by mutually affording a market, give a good deal of encouragement to each other's industry" (Smith, 1776). This statement, however contentious from the point of view of the growth of industries in the colonies was true in terms of the benefits accruing to the British Empire. Direct control subjugated these colonies through administrative, commercial, judicial, and other controlling systems. By the late Eighteenth Century Britain had become a nation that was "sending out its ships to explore every distant sea; its factors to open up commercial intercourse with every affluent coast" (Wilson Anti-Slavery Collection, 1840). The greater part of Asia's littoral and islands, of which the British Empire was a component, was integrated into the world economy during the first sixty years or so of the nineteenth century. The indigenous shipping industries became confronted with European maritime, technological, economic and political expansion that together formed the main dynamics of the ensuing age of Western domination.

Overseas trade and Indian shipping were greatly disadvantaged even before this integration was well-established because of technological backwardness. Steam shipping from the beginning was dominated by Western ship owners, until the Asian colonies achieved full political independence after 1945. Since the late 1960s, South Asia has witnessed - or, rather, created - a dramatic resurgence of its involvement in shipping. The main objective of this chapter is to examine how the end of the British Empire, by bringing independence to the colonies, restructured their trade patterns and shipping networks (Broeze, 1987, 1996; Bracken, 2015). By contrast with economic history and international economics, this chapter uses data on vessel movements instead of trade data over the period 1890-2000, i.e. during 
the heydays of colonialism and after the independences. The advantages of using vessel movement data published in the Lloyd's Shipping Index are numerous: vessels carry most commodities; the data covers a long period; is disaggregated at port level; and is relatively neutral as it is collected due to the non-governmental nature of the organization, i.e. unaffected by interruptions caused by political changes.

Our geographical coverage is primarily focused on former British India, while "South Asia" includes Pakistan, India, Myanmar (Burma), Sri Lanka, and the Maldives. This chapter contributes to the literature in the economic history of international trade in South Asia by providing a detailed analysis of historical shipping data. It questions whether and how political and economic evolutions affected the pattern of maritime networks in this area. Such an approach takes its inspiration from relatively few earlier studies of the kind. Todd and Zhang (1993) and Wang and Ducruet (2013) studied the impact of political or economic change on port activities in China, while Iheduru (1996) analyzed the effects of dismantled Apartheid on South Africa (for other analyses of transnational port systems, see Chapters 5 , 8, 9, 11, 19, and 23 on Taiwan Strait, Black Sea, Arctic, Mediterranean, USSR, and Northwest Africa).

\section{Data and methodology}

In order to measure and map shipping flows connecting South Asia inwards and outwards at various levels, we extracted vessel movement data from the Lloyd's List corpus (see Ducruet et al., 2015 for a detailed description). The information contained in the Lloyd's Shipping Index documents vessel characteristics, ports of origin and destination as well as the latest ship voyage on the date of the publication. We do not exlude a bias in our methodology, since the analysis focuses on the months of April or May every 5 years, due to the seasonality of trading flows. In South Asia, interrelated seasonality includes both weather and production factors, such as the rainy season marked by cyclones, which in turn affects the agricultural production (i.e. early harvesting period) of jute, which takes place after the rainy season. Seasonality may exclude certain ports from the sample if the specific commodity they trade relates to another season than spring. In turn, this possible drawback is compensated by an extraction at the same period for comparability and consistency. Secondly, data mainly documents oceanic or deep-sea voyages, leaving aside domestic fleet performing local trades (i.e. coastal shipping), as the Lloyd's principal purpose was the insurance of international trading vessels. Despite their smaller size, such domestic vessels may have an important role for cargo redistribution between global and local trade routes, such as junk vessels in China (Wang and Ducruet, 2013). 
Thirdly, the number of ships and ship calls, which are the traffic measurement units retained in this study, do not account for the true freight volume (or value) of flows. Yet, the retained unit has the advantage to be comparable overtime. Fourthly, the actual routes of ships are in reality more complex than direct single port-to-port lines, thus missing successive and intermediary stops. Each segment between two ports is part of a longer voyage between origin and destination ports, regions, and continents, making it impossible to differentiate between intra- and extraregional flows. In terms of timeline, 1890 coincides with the middle of the "British Raj" (1858-1947), with a steady demographic growth and a rapid development of India's private industries accompanied by heavy investments in physical infrastructures such as railways, canals, roads, and ports, up to the globalization era (Ghosh and De, 2001).

Following a steady work to disambiguate country and port names based on current names, we define routes as links between port pairs created by the movement of at least one ship. The number of vessel calls is measured at the level of ports, countries or regions as well as by interport link. Domestic routes are within the territory of a current country, while regional routes are within South Asia and international routes connect South Asia with the rest of the world.

\section{Vessel movement distribution in South Asia}

The direct or indirect British rule was gradually established in most of the regions in South Asia, from 1757 after the Battle of Plassey. By 1890, the starting date of our dataset, the British governed almost the entire region. ${ }^{1}$ For Myanmar (Burma), Lower Burma came under British control from 1826 and was annexed in 1853, whereas Upper Burma in 1886. The British also directly governed Maldives from 1887, Sri Lanka (Ceylon) from 1815 and ceded around a third of Nepal's territory in 1816.

The World War II resulted in both political as well as economic disruption in the region. The Japanese invaded and controlled Burma between 1942 and 1945, and also attacked the Indo-Burma border in 1944. The end of the War brought momentous changes in the form of freedom from colonialism in most of South Asia. After the long struggle for its independence, British India got separated into two nations, Pakistan and India in $1947 .{ }^{2}$ Pakistan had two territories in the East and West of India. In East Pakistan, conflicts built around the issue of

\footnotetext{
${ }^{1}$ Some parts of India were governed indirectly as princely states. Details of historical accounts of various British colonies can be found for example in Carrington (1950).

${ }^{2}$ Princely states later joined either Pakistan or India.
} 
language and suppression of election results triggered the war of independence. Consequently, East Pakistan became independent as Bangladesh in 1971.

Burma had been separately administered since 1937 and got independent in 1948. As the socialist movements advanced, coup-dater occurred and military government had claimed the Burmese socialistic state since 1962. These changes disconnected economic relations with Western countries. ${ }^{3}$ Ceylon was granted independence in 1948 and was given a Dominion status within the British Commonwealth, which was retained for the next 24 years until May 22, 1972, when it became a republic and was named the Republic of Sri Lanka. Independence for all these countries meant a complete overhauling of the international trade networks. In the following sections, we discuss our data at three levels of aggregation, from South Asia to the present day countries and their port cities.

\section{South Asia}

The evolution of ship calls within South Asia (Figure 24.1) starts with 1,060 movements in 1890, covering 330 inter-port linkages among the 23 ports appearing in the database. International calls were already about $77 \%$ of total flows. From 1890 onwards, the number of calls witnessed certain fluctuations such as a rapid but temporary decline during the independence of the Indian subcontinent, and a rapid growth afterwards.

Intra-regional flows oscillated around $30 \%$ of total flows throughout the period (Figure 24.2). Prominent declines are observed for extra-regional flows, such as with the United Kingdom from $33 \%$ in 1890 to $24 \%$ in 1935, around $8 \%$ in 1965 and only $1 \%$ in 2000 . Flows with the Middle East increased from around 3-5\% before 1945 to around $12 \%$ in the 1980 s and the 1990s. Routes with East Asia and Southeast Asia also increased. East Asian routes increased from around 3\% in 1890 to $10 \%$ in 1935 and remained so after 1945. For Southeast Asian routes, the share was around 3-5\% in the 1900s but increased after 1945 to $17 \%$ in 1980 and $35 \%$ in 2000 . These trends clearly show the unchanged importance of intra-regional routes and the shifts from European routes to East and Southeast Asian routes after 1945. These trends both reflect trade and logistical changes. For the latter, operational and technological evolution of the port and maritime industries moved from direct port-to-port shipping to pendulum services and hub-and-spokes configurations along the Europe-Asia route, with intermediary stops, especially with the advent of containerization. This can accentuate the gap or uneven overlap between shipping patterns and trade patterns as discussed earlier.

\footnotetext{
${ }^{3}$ Under one-party system, due to the failure in economic policies, high inflation was severe and democratization movements advanced in 1988. The military government had kept their power by declaring martial law and suppressing free election in 1990. See, for example, Topich and Leitich (2013) in detail.
} 
[Figure 24.1]

[Figure 24.2]

The cartographic representation of South Asian maritime networks only retains the most voluminous flow link for each port node decade wise (Figure 24.3). Although such an operation obliterates a vast quantity of information, it also allows the emergence of a clearer pattern of port hierarchies and corridors in a given region. In the first half of the period (1890-1940), the eastern and western parts of the region connect via one major link, namely Kolkata-Mumbai, the largest flow connecting the two largest nodes in India. However, Kolkata's main shipping link shifted from Mumbai to Colombo from the 1920s onwards. Another feature is the much denser distribution of shipping linkages in the eastern part of the region, or the Bay of Bengal, where Kolkata and Yangon act as the most powerful hubs with the largest connecting flows. It means that many second-order nodes depend on them to ship their goods through the network. Mumbai, on the other hand, has a large size but its role as a hub is far less significant. From the 1950s onwards, Mumbai took over as the major port in India while Kolkata started loosing its significance due to natural causes of siltation and inability to handle bigger ships (Murphey, 1964; Kidwai, 1992).

In the second half of the period (1950-2000), the major Mumbai-Kolkata link resumes temporarily (1950-1960). Kolkata remains the regions' largest node (in terms of total vessel calls) and largest hub (in terms of maritime centrality) until 1970. Afterwards, while Mumbai takes the lead in terms of traffic size, the whole network tends to split among several lowconnected subsystems, the eastern and western parts loosing interdependency. New second-order hubs emerge, such as Chennai and Visakhapatnam, while some formerly major nodes such as Yangon nearly disappear from the map. The figures until 2000 confirm that successive independencies (in addition to other factors) gradually resulted in the split of the networks' backbone into several disjointed parts. In parallel, the amount of maritime activity and the density of shipping linkages are more evenly distributed between east and west parts in the recent decades. One influencing factor is the emergence of new ports outside traditional port cities that distort inherited shipping patterns (Kidwai, 1989; Eliot, 2003). In the following section, we examine the data at country level and port level in each country. ${ }^{4}$ A comparison of the dynamics of individual countries is provided in Figure 24.4 based on their foreland distribution.

[Figure 24.3]

\footnotetext{
${ }^{4}$ We omit the results for Maldives since it has low frequency in our data. In brief, there were 18 calls, and 4 international routes, throughout the period, with a first appearance in 1965 that became continuous only after 1985.
} 


\section{Bangladesh}

The changes in the number of calls and routes for Bangladesh are significant. Results show a clear increase after 1945, which corresponded to the partition of India in 1947. During the colonial period, the number of calls was on an average 18.8 with its minimum at 6 in 1915 and maximum at 44 in 1930. The average number of routes was 10.7. Throughout the colonial period, only Chittagong was connected, so that no domestic route appeared. The composition of international routes fluctuated significantly throughout the 20th century. Since jute was the primary export item from Bangladesh in the nineteenth and early twentieth century, the routes to the United Kingdom were mainly to Dundee, Glasgow, Liverpool and London. Other than these Aden, Hamburg, and some East African ports also appeared.5 It was in 1950 when another port, Khulna (Chalna), appeared in the list $^{6}$, followed by Mongla in 1990. The number of calls per route after 1950 was only 1 to 3 and the destinations were diversified.

[Figure 24.4]

Singapore appears as an important port after 1950. The number of calls increased from 3 in 1951 to 32 in 1980 and to 71 in 2000. For the regional trade during the colonial period, the trading ports were Kolkata, and Tuticorin in India and Sittwe and Yangon in Myanmar. It should be noted that Dhaka appears in the list only once; as an upstream port, its depth is not sufficient for international vessels.

As mentioned earlier the region of current Bangladesh had been East Pakistan prior to 1971. As the trade between West and East Pakistan became important, vessel movements begin to appear in the data. There were 5 voyages between East and West Pakistan for the first time in 1950, 3 in 1960, 12 in 1965, and 16 in 1970.7 After the independence of Bangladesh, this trend changed but not vanished. There were 6 voyages in 1975 and between 3 and 6 from 1980 to 2000. On the other hand, regional routes with India increased once Bangladesh became independent. Between 1950 and 1985, the average number of calls between India

\footnotetext{
${ }^{5}$ Exports of jute were predominantly dispatched from Kolkata. Chittagong served as a minor port. The export quantity of jute in million maunds was, for example in 1894-95, 12 from Kolkata and 0.4 from Chittagong (Ahmad, 1958, p. 258).

${ }^{6}$ Khulna port opened in 1951. In the second half of the first year, the total trade amounted at 16.5 million rupees, $98 \%$ being Pakistani merchandise. On the other hand, cargo trade for import was not only with Pakistan and for export it was totally with other foreign countries (Ahmad, 1958, pp. 264271).

${ }^{7}$ The capacity of Chittagong port had substantially increased. The number of handled cargo increased around 15 times from 1945 to 1955 (Ahmad, 1958, p. 270).
} 
and Bangladesh reached 21 whereas they were only 4.2 during the colonial period. The peak was reached in 1960. After 1985, the number of calls decreased to around 8. Domestic routes were only 4 in 1960 and increased to 34 in 1985. It decreased in the 1990s but increased to 24 in 2000.

\section{India}

India's location in the middle of Indian subcontinents gives it a long coastline, and it has the historical advantage of having the main ports in the subcontinent from the colonial times. Thus, the number of vessel calls from here had always been the highest in the region. In 1890, there were 672 calls, 163 routes and 15 ports in India. International calls were $76.8 \%$ and regional calls $8.9 \%$. From 1915 to 1925, there was a substantial growth in terms of calls from 552 to 985 , with some decline until 1940. The number of routes clearly increased in 1925 but not in 1915 and 1920, which does not correspond with the increase in the number of calls. The major ports were Kolkata and Mumbai before the independence. In 1890, the share of these two ports was $87.8 \%$ and $69 \%$ at lowest in 1940 . When we compare the ship call data with the cargo handled data we find a comparable picture which corroborates the pre-eminence of these ports in the port hierarchy (Kidwai, 1992). Between 1880 and 1950, Kolkata and Mumbai have been the first two top ranking ports in India in terms of the cargo handled (Kidwai, 1992). Port primacy had shifted from Chennai to Kolkata after its establishment in the late seventeenth century and remained with it well until the end of the nineteenth century. The primacy shifted between Kolkata and Mumbai between 1900 and 1950 and as a deviation of Kolkata's main shipping link from Mumbai to Colombo from the 1920s onwards, while loosing some of its traffic and rank to Mumbai.

After 1945, the trend reversed and substantial growth occurred, from 632 calls in 1945 to 1,059 in 1965. A noticeable decline again is observed in the 1980s followed by an increase in 1990 at around 1,000 calls. Kolkata and Mumbai continued to remain the main ports after India became independent but the share of these two ports steadily decreased down to $19.6 \%$ in 2000 . This was mainly caused by the emergence of other ports in the country such as Chennai, Kandla, Mormugao and Visakhapatnam.

After 1945, the number of routes and ports in India continuously increased until 1975 and remained stable. The average share of international calls remained around 71 percent before and after 1945. In terms of regional trade, India had frequent connections with Sri Lanka (30 calls on average) and Myanmar ( 40 calls on average) during the colonial period. After 1945, the routes with Sri Lanka continued but the ones with Myanmar decreased to less than 10 calls 1970 onwards. Routes with Pakistan were slightly more frequent during 
the colonial period with an average of 22.2 , which reduced to 20 after the partition of the countries.

\section{Myanmar}

Across the Bay of Bengal, Myanmar has historically traded with Indian ports. However, the number of calls decreased after the independence of the country and after the establishment of the Socialist regime.

In 1890, the 218 calls and 97 routes of Myanmar witnessed important fluctuations until 1945.8 In the post-colonial period a growth is observed from 1950 onwards with a peak in 1960 followed by a decline until 1975.9 This decline continued thereafter at a faster rate. On average, there were 176 calls during colonial period which decreased to 68 after the independence and 44 after 1970. Similar trends are found for the number of routes as well. Domestic calls are recorded until 1965 but disappear after 1970. The share of regional calls had two spikes in 1920 and 1945. Both corresponded to the timing of the local lows in the trends, which indicates a decrease in international calls and a less significant fluctuation in regional calls. After 1970, there was a clear expansion in the share of international calls to Southeast Asia, with Singapore as the main destination.

Yangon was the major port in Myanmar and Sittwe, Mawlamyine and Pathein were secondary ports that had more than 10 calls at least once in the sample years in our data.

\section{Pakistan}

The data on Pakistan shows a gradual increase during the colonial period and from 1950 after independence. The growth after 1950 was led by the expansion of international routes and calls. The first spike is downwards in 1900 and shows a sharp decline in international calls, which became about one sixth of 1895. The second spike is upwards in in 1925 and was led by the expansion of international calls to UK and Europe. The third spike in 1975 was

\footnotetext{
${ }^{8}$ Despite the Depression of the 1930's, the number of calls peaked in this period. This corresponded to the trends in export volumes from chief Burma ports for the same period shown in Table 30 (Andrus, 1948, p. 216). On the comparative number of calls, in 1940, there were 1,377 steamers entering Yangon (Rangoon) whose traffic, exclusive of Burmese coastal traffic, was at least 828 (Andrus, 1948, pp. 214-215).

${ }^{9}$ The recovery to the pre-war level was not easy because the disruptions during war period were devastating (Andrus, 1948, pp. 202-211).
} 
driven by the expansion of calls to almost all of the regions, as in 1965.10 The major port in Pakistan was Karachi throughout the century ${ }^{11}$. From 1985 Port Muhammad Bin Qasim appears as its secondary port. Gadani Beach and Gwadar also appeared in our data only four times with less than five calls and twice with only one call.

The domestic calls do not appear consistently and their number was as low as six or less. The regional calls with India, on the other hand, appeared constantly for the entire period. The destinations in India were mainly Mumbai and Kolkata. Colombo a also consistently appeared from 1945. As discussed in the section on Bangladesh, the geographical separation of East and Western Pakistan resulted in domestic trade being carried only by maritime shipments. This route had appeared after the partition of the countries and decreased in frequency after the independence of Bangladesh. The share of regional calls was more than 20\% until 1970 but remained under 15\% until 1995.

During the colonial period, the United Kingdom had a high share in Pakistan's international trade, with an average of 42 percent, like the rest of Europe (31 percent). The opposite trend occurred with the Middle East and Southeast Asia, with their respective shares increasing from $10 \%$ and $2 \%$ during the colonial period to $27 \%$ and $20 \%$ after 1985 . It is interesting to note that while the routes to the Middle East are evenly distributed among different countries, the routes to Southeast Asia are mostly to Singapore.

\section{Sri Lanka}

The traffic evolution of Sri Lanka drastically differs from the rest of the region, with less differentiation between colonial and post-colonial periods. While certain fluctuations are observed, most of the variables in our data are stable within certain ranges. For example, the number of calls started at 114 in 1890 with a minimum at 94 in 1895 and a maximum at 275 in 1990. The major port was Colombo and the secondary ports were Galle and Trincomalee.12 The other ports had a minor role with less than ten calls on average, such as Point Pedro, Jaffna, Pulmoddai, Hambantota, and Kankesanturai.

\footnotetext{
${ }^{10}$ On the capacity of the port, "Since Partition, the storage capacity has been increased substantially" and "ambitious" expansion had been installed by 1961. "In 1947 two shipping companies registered in Pakistan" and "by 1956, the seven shipping companies registered" for twenty merchant ships (Andrus and Mohammed, 1958, pp. 244-249).

${ }^{11}$ In 1843, "Karachi was a fishing village and small port with a population of only 14,000" (Andrus and Mohammed, 1958, p. 243).

12 Until the 1870s, the total shipping tonnages of Galle was larger than the one of Colombo. After the intensive investments in Colombo port in the 1880s, Colombo reached 80 percent of Sri Lankan trade value (Dharmasena, 1985).
} 
The destinations became more international as the average share of international calls was 65.5 percent in the colonial and 72.0 percent in post-colonial periods. The average share of regional calls was 32.1 percent in the colonial and 25.4 percent in the post-colonial periods. One noticeable change in the trends is the increase in the share of international calls to Southeast Asia from an average of 7 percent during colonial period to 22 percent after 1985 .

\section{Conclusion}

With the newly available data of vessel movements, we have examined the historical evolution of maritime networks in South Asia and its component countries and ports. One main result is to show that such networks were reconfigured after these countries achieved their independence from the colonial rule. These changes were very pronounced in Bangladesh, Pakistan and Myanmar, that changed their politico-economic relations, such as the increased significance of Bangladesh and Pakistan. As it served as the hinterland of Kolkata, Bangladesh's disconnection with Kolkata after the partition led the substantial growth of Chittagong. The number of calls were nearly ten times more than the level during colonial period. Myanmar is a contrasting example. Its good connection to international markets through rice exports was impacted by the independence, especially due to the insular policies of the Socialistic military government. Within India, the pattern of port hierarchies remained somewhat stable overtime, notwithstanding the emergence of secondary hubs and a reorientation from British dominance to a polarization upon Southeast Asia and the Singapore hub.

There are, at least, two points to discuss from these contrasts, institutional changes and regional structures. Institutional changes are critical for the stable trade relations. As Myanmar took the radical step for Socialism, the trade relation dramatically disappeared. Such changes were clearly shown from the vessel movements. Second is the regional structure. As each port represents its hinterland, the trade linkage on the land is also reflected on its rise and fall, i.e. the rise of Chittagong reflects its disconnection from Kolkata. Similar cases can be found in Punjab and Karachi. Further research shall refine the analysis of the impacts of specific events and concentrate on hinterland dynamics in response to the rise and fall of port cities.

No consistent pattern has been followed by the Indian ports in terms of their growth in shipping and their ranks in the port hierarchy. However, the general trend in the colonial period was that the colonial ports showed positive growth whereas the pre-colonial and intermediate and minor ports remained stagnant or indicated insignificant growth. This pattern changed in the post independence period and then again in the post-Reform period 
after 1991. The primate ports now show a relative loss of cargo handled and hence shipping in comparison to the intermediate and minor ports. In the post Reform period the Indian port system is no more path-dependent and is responding to the contingencies surfacing from the globalization and containerization process in the country (Kidwai, 2013).

Further research shall investigate how vessel movement data can reflect the two port policies of India and China, which are the big economic and strategic players in the Indian Ocean region. Under its "String of Pearls" strategy, China has set up ports in strategic maritime countries such as Myanmar and Pakistan. It also proposes to set up ports in Bangladesh, Sri Lanka, and the Maldives. These countries will attract Chinese shipping hubs to their own ports on foreign soils. India too has created a "Sagarmala" (Garland of the Oceans) port project under which six new major ports will be set up. India also has an "Act East" policy. Consequently, the newer state owned and captive private ports on the east coast, which have been geared to the demands and specifications of international trade, especially with China and their Asian trade block, are increasing their share of cargo and are growing very fast.

\section{Acknowledgements}

We gratefully acknowledge financial support from the Institute of Developing Economies, JETRO. The research leading to these results has received funding from the European Research Council under the European Union's Seventh Framework Programme (FP/20072013) / ERC Grant Agreement n. [313847] "World Seastems".

\section{References}

Ahmad N. (1958) An Economic Geography of East Pakistan. London: Oxford University Press.

Andrus J.R. (1948) Burmese Economic Life. Stanford: Stanford University Press.

Andrus J.R., Mohammed A.F. (1958) The Economy of Pakistan. Oxford: Oxford University Press.

Bracken G. (2015) Asian Cities: From Colonial to Global. University of Amsterdam Press.

Broeze F. (1987) From imperialism to independence: The decline and re-emergence of Asian shipping. The Great Circle, 9(2): 73-95. 
Broeze F. (1996) The ports and port system of the Asian seas: an overview with historical perspective from c. 1750. The Great Circle, 18(2): 73-96.

Carrington C. (1950) The British Overseas: Exploits of a Nation of Shopkeepers. London: Cambridge University Press.

Dharmasena K. (1985) The port and dock workers of Colombo 1860-1960. The Great Circle, 7(2): 100-115.

Ducruet C. (2015) Inter-Korean maritime flows: Beyond the border? Portus, 30: http://portusonline.org/inter-korean-maritime-flows-beyond-the-border/

Ducruet C., Haule S., Ait-Mohand K., Marnot B., Kosowska-Stamirowska Z., Didier L., Coche M.A. (2015a) Maritime shifts in the contemporary world economy: Evidence from the Lloyd's List corpus, 18-21 c., In: Ducruet C. (Ed.), Maritime Networks: Spatial Structures and Time Dynamics, London and New York: Routledge Studies in Transport Analysis, pp. 134-160.

Eliot E. (2003) Chorotype de la métropole portuaire d'Asie du Sud. Mappemonde, 69: 7-10.

Ghosh P., De P. (2001) Indian ports and globalisation: grounding economics in geography. Economic and Political Weekly, 36(34): 3271-3283.

Iheduru O.C. (1996) Post-Apartheid South Africa and its neighbours: a maritime transport perspective. The Journal of Modern African Studies, 34(1): 1-26.

Kidwai A.H. (1989) Port cities in a national system of ports and cities: a geographical analysis of India in the 20th century. In: Broeze F. (Ed.), Brides of the Sea: Port Cities of Asia from the 16th - 20th Centuries, Honolulu: University of Hawaii Press, pp. 207-222.

Kidwai A.H. (1992) Conceptual and methodological issues: Ports, port cities and port hinterlands. In: Banga I. (Ed.), Ports and their Hinterlands in India, 1700-1950, New Delhi: Manohar Publications.

Kidwai A.H. (2013) Ports as infrastructure, ports as cities: The Indian port system from colonialism to globalization. Project Report, Indian Council for Social Science Research, India.

Murphey R. (1964) The city in the swamp: aspects of the site and early growth of Calcutta. The Geographical Journal, 130(2): 241-256.

Smith A. (1776) An Inquiry Into the Nature and Causes of the Wealth of Nations. London: Methuen \& Co., Ltd.

Todd D., Zhang L. (1993) Political and technical factors impinging on port operations: The case of Manchuria. Geojournal, 30(4): 441-454. 
Topich W.J., Leitich K.A. (2013) The History of Myanmar. Santa Barbara, CL: Greenwood.

Wang C., Ducruet C. (2013) Regional resilience and spatial cycles: Long-term evolution of the Chinese port system (221BC-2010AD). Tijdschrift voor Economische en Sociale Geografie, 104(5): 521-538

Wilson Anti-Slavery Collection (1840) Present condition of British India, 1840. The University of Manchester, John Rylands University Library. 


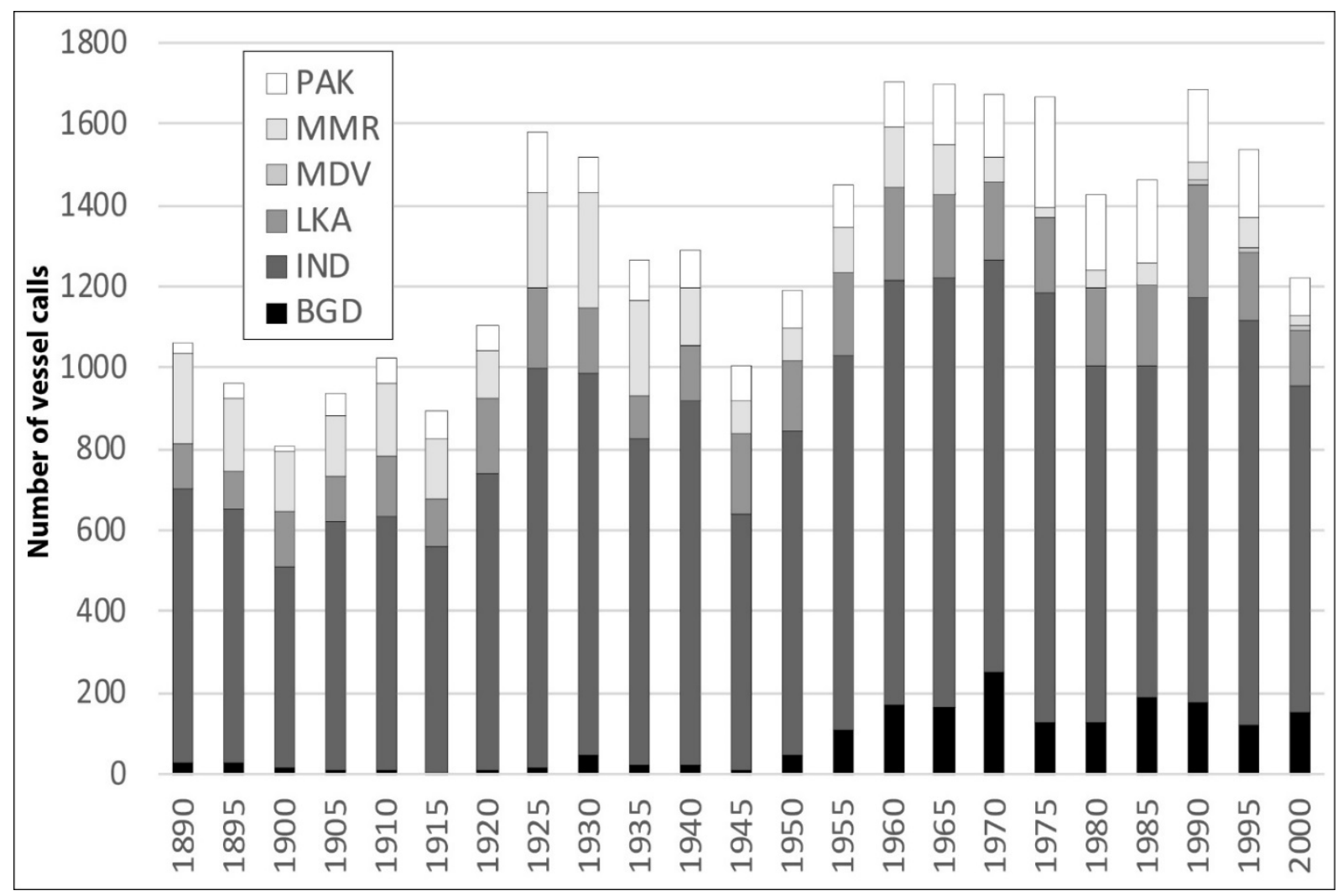

Figure 24.1: Shipping traffic distribution of Indian subcontinent ports by country, 1890-2000 Source: own realization based on Lloyd's List data 


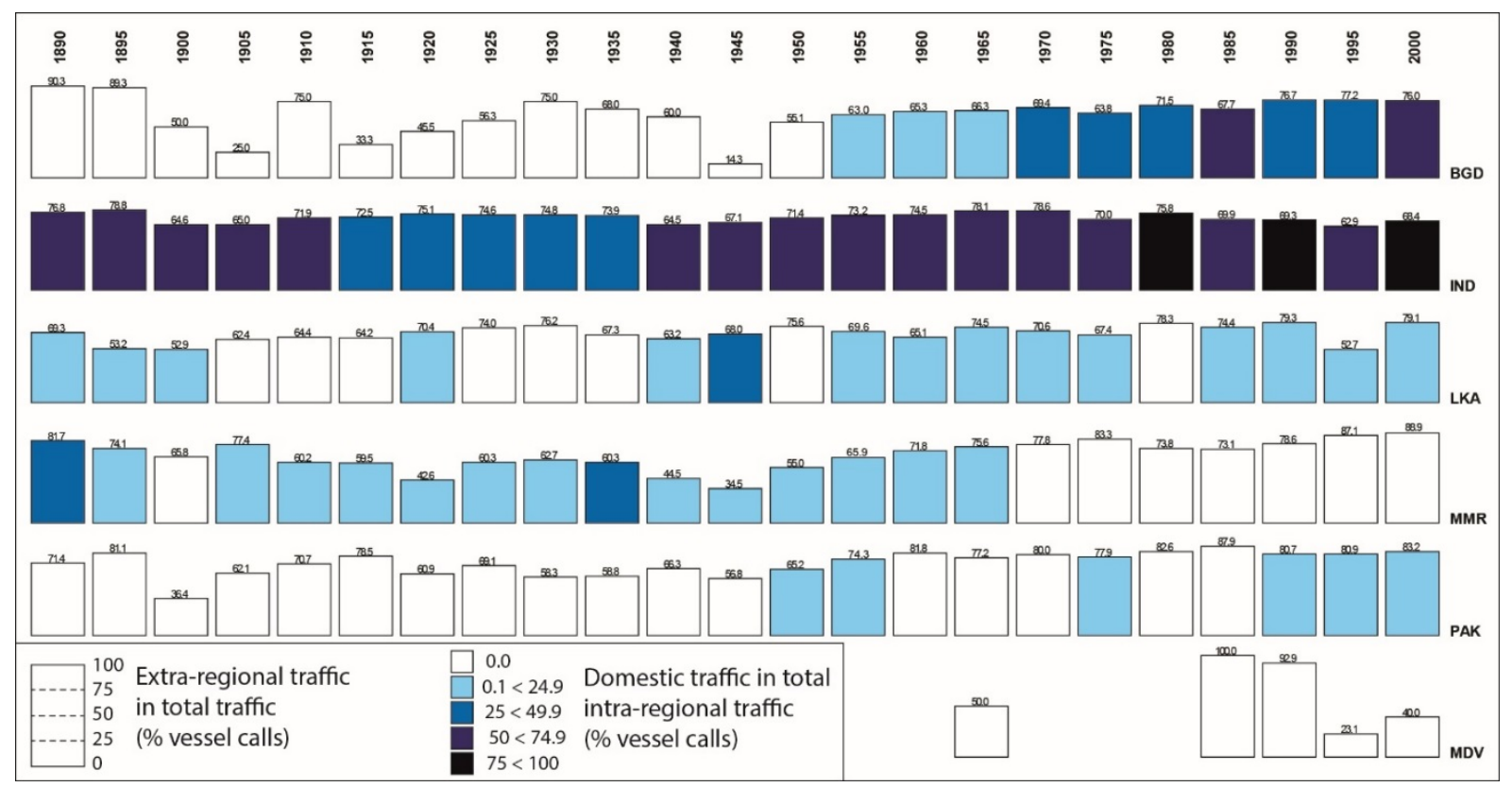

Figure 24.2: Distribution and connectivity of Indian subcontinent shipping flows, 1890-2000

Source: own realization based on Lloyd's List data 


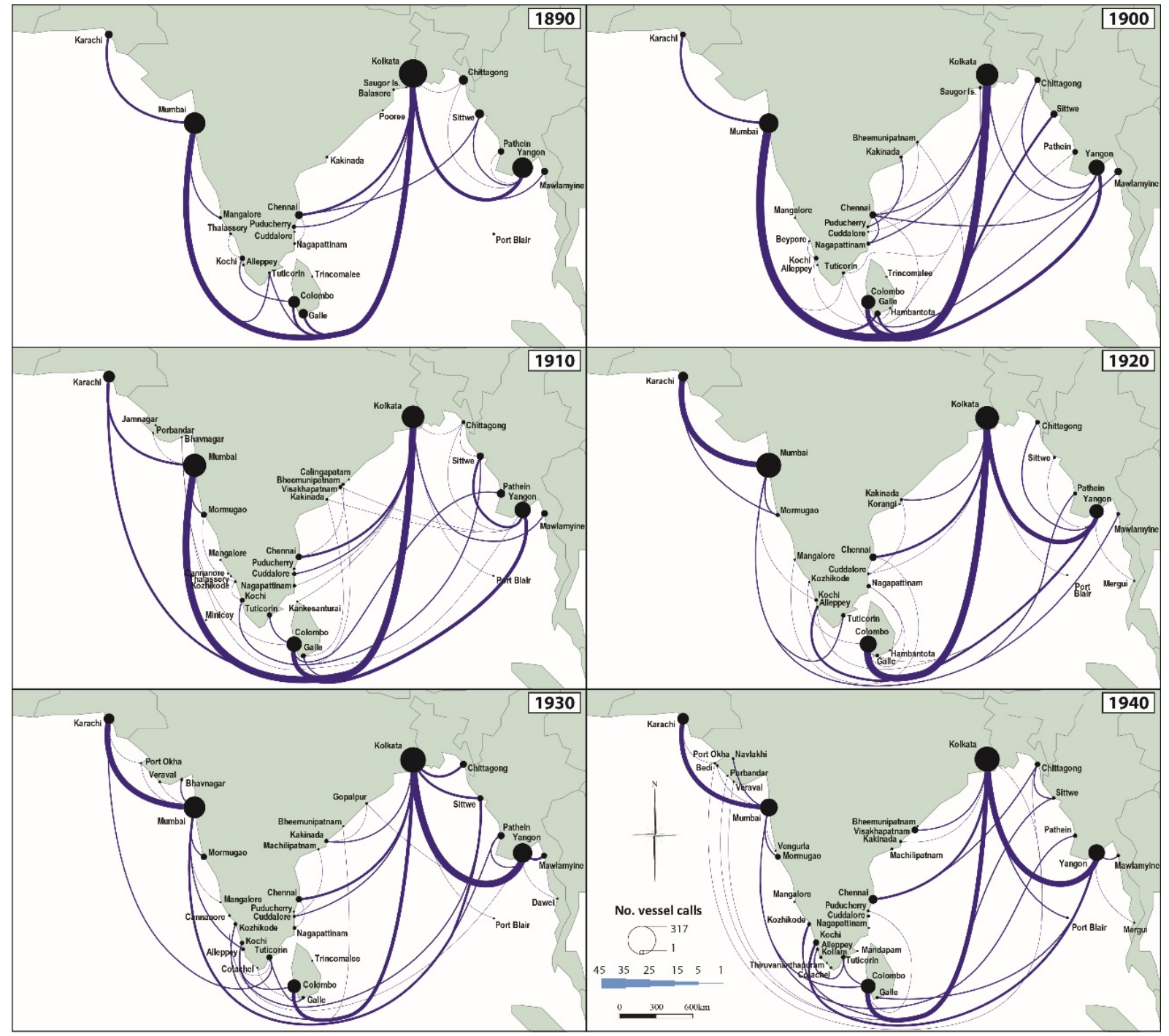

Figure 24.3: Spatial distribution of major Indian subcontinent shipping flows, 1890-2000 Source: own realization based on Lloyd's List data 


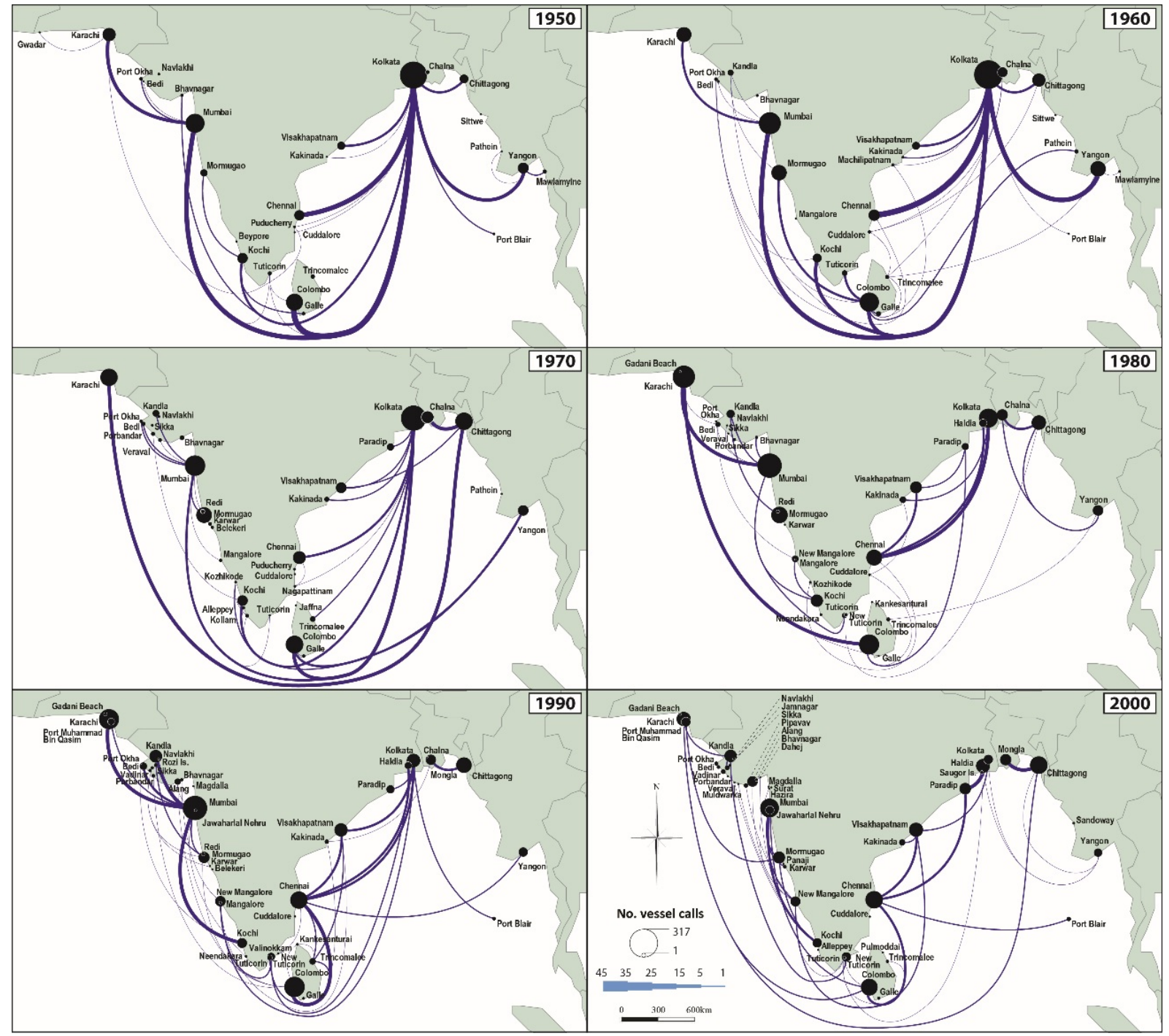

(continued) 


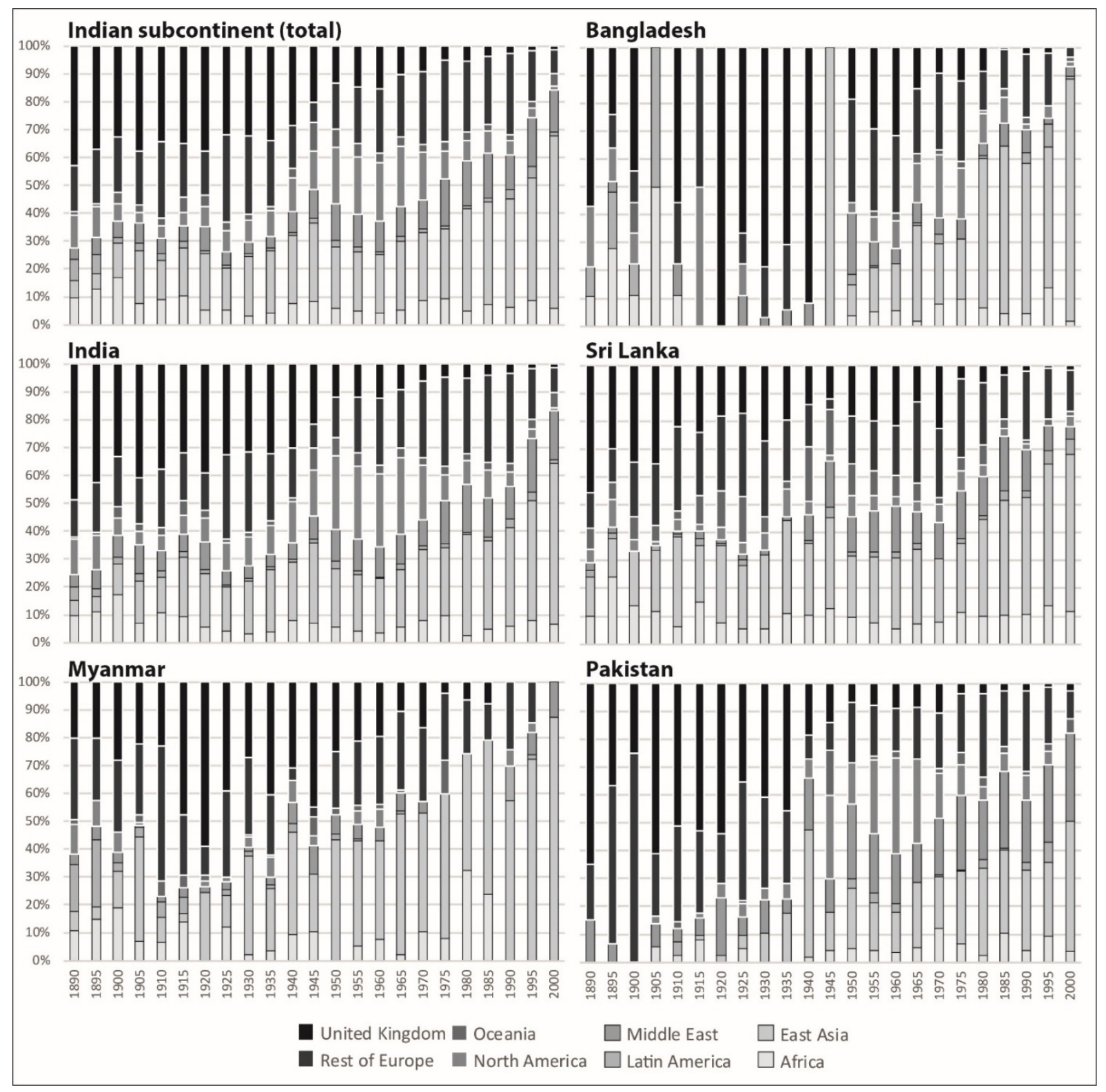

Figure 24.4: Shipping traffic distribution by (destination/origin) regions, 1890-2000

Source: own realization based on Lloyd's List data 